\author{
Миливоје В. МЛАЂЕНОВИЋ* \\ Педагошки факултет Сомбор
}

Оригинални научни рад

Примљен: 11. 03. 2020.

Прихваћен: 15. 07. 2020.

\title{
ОБЕЛЕЖЈА ДРАМСКОГ У ЖИТИЈУ СВЕТОГ СИМЕОНА СВЕТОГ САВЕ
}

\begin{abstract}
Естетски појам драматичног, садржински означава, између осталог, кретање у супротностима, борбу идеја, дисонантност егзистенције. Полазећи од те категорије, у раду се најпре установљавају најзачајнија обележја драмског у Житију Светог Симеона: сценске слике, дијалог, монолог, сукоб, драмске ситуације, драмски ликови и друга својства која ће потом бити подвргнута анализи. Њихове најбитније какарактеристике биће описане на најупечатљивијим примерима узетим из овог значајног списа Светог Саве које одише несвакидашњом узбудљивом и поетском атмосфером. У закључку ће бити истакнута драматска снага Светога Саве у сликању сцена немањићке земље дванаестог и тринаестог столећа, која је упоредива са сценама из античке драме.

Кључне речи: житије Светог Симеона, Свети Сава, драма, дијалог, монолог, сукоб, драмска ситуација, ликови.
\end{abstract}

Неки описи у спису Светог Саве упућују на удаљену сродност са структуром црквених приказања, мистерија. „Сматра се да описивање живота светаца вуче корен из свеобухватне повести која доживљва врхунац у Спаситељевој жртви и да је то 'подражавање' истих догађаја који су претходно уобличени у Старом завету” (Молинари 1982: 96). Обредне радње, на пример, везане за догађаје из живота Стефана Немање подсећају на поступке карактеристичне за позориште средњег века. Имају неке одлике црквеног обреда који се такође може посматрати као рудимент позоришног представљања.

Драмске ситуације: однос имеђу Стефана Немање и Светог Саве, психолошки однос, унутрашња природа, деловање ликова, детерминишу индикације које, скривене у тексту, служе за разумевање мотивације и дејствовање ликова: „А ја, павши на лице његово, плаках горко дуго часова”, „велика туга и бојазан ме обузеше”, „мене - недостојног и умањеног у свему, позва, са тихошћу...” Драмско се не очитује увек у приповедању које има напетост, очекивање. Често и привидно статична ситуација која је дата као портрет оца 
Симеона, или слика природе, опис манастирског пејсажа, делује као припрема за следећу драматичну епизоду. Све такве ситуације у спису Светог Саве Житије Светог Симеона представљају драмске ситуације које учествују у изградњи фабуле и радње. Дескриптивни моменти обележје су прелаза из једне у другу драмску ситуацију.

Дијалог, као основа и најрепрезентативнија одлика драмског текста привидно није доминантан у овом делу. Делатни ликови Житија господина Симеона, Свети Сава и Стефан Немања, делују природно, уверљиво, веродостојно. Њиховим дијалогом постиже се најјачи утисак стварног код читаоца. Теоретичари драме сматрају да монолог „није у складу са захтјевом за вјеродостојношћу међуљудских односа" (Павис 2000: 54). Међутим, у спису Житије господина Симеона једнако потресно, а веродостојно делују и монолози Стефана Немање. Они нису вербални украс, њихову веродстојност оснажује стално, ненаметљиво присуство саговорника, Светог Саве. Његове су реплике, углавном кратке: „А ја му рекох”, „А ја сам на све то рекао: Амин” ...итд. Према типологији дијалога, говорној размени у Житију господина Сuмеона, најближи је дијалог какав налазимо у класичној трагедији: тираде, монолози су изграђени на чврстој реторици: Симеон излаже свој поглед на свет, а Сава се у позицији скрушеног, љубављу оданог сина, „уклапа” у његов контекст, саглашава или појачва значење узвишеног. „Многих и великих дарова насладих се од тебе, блажени господине мој Симеоне! А забораван за све, показах се, јадан и некористан, изједначих се са стоком несмисленом и уподобих се њима...” (Свети Сава 1998: 177). У овом примеру, захваљујући ословољавању, постигнут је скоро учинак натуралистичког, свакодневног говора. Томе доприноси, и плач, као опште место, честа књижевна врста у средњовековној књижевности. У самртном тренутку када Немања „пребожаствени дух свој испустивши, усну у Господу” (Свети Сава 1998: 183), Свети Сава говори: „А ја, павши на лице његово, плаках горко дуго часова, и уставши, блгодарих Богу што сам такав крај видео овог преподобног мужа" (Свети Сава 1998: 183). У спису Светог Саве има више драмских ситуација обележених плачевима. Ваља разликовати индивидуални плач Светог Саве од колективних плачева. Ридања Светог Саве су само наговештена, дата је само њихова назнака и они се претапају у монологе несумњиве веродостојности. Посебна вредност монолога Светог Саве јесу његове дијалошке црте. То бива у драмским ситуацијама у којима се Свети Сава налази у дилеми и комуницира са имагинарним слушаоцем, односно публиком: „Јер како овога да назовем? Владарем ли, или више учитељем? Јер утврди нас и уразми срца свих и поведе нас како треба правоверни хришћани да држе праву веру према Богу” (Свети Сава 1998: 151). Још је снажнијим драмским расположењем испуњена драмска ситуација која представља уклањање Стефана Немање од народа који „плакаху и ридаху, гледајући растанак од таквог господина и пастира" (Свети Сава 1998: 163). Тада Свети Сава изговара вапајни монолог молећи имагинарне слушаоце да саучествују у разрешењу недоумице, како да именује Стефана Немању: „Јер како да га назовем, ваистину, недоумевам се, Господином ли добрим? Учитељем ли правоверја? Оцем ли благим? Па- 
стиром ли, који вером напаса стадо му предато? Црквама ли просветитељем и добрих обичаја учитељем и у молитвама вазда пребивајућег? Ништих ли преизобилног служитеља и љубитеља? Правоверја ли наставником и добре вере учитељем и чистоте, засењен светилом"? Упркос недрамској природи монолога, Савине тираде артифицијелно снажно, лирски интониране, универзалним рефлексијама о животу и смрти делују драмски потентно, творећи засебну целину која би се могла посматрати као драмска форма са једним снажним ликом. Симеон окупи „благородну своју децу и све изабране своје бољаре, мале и велике" (Свети Сава 1998: 155) да им саопшти своју одлуку „да се уклони од народа” и „изиђе од владавине своје” и потражи спасење у манастиру. Колективни плач, ридање и сузе праћене говором, имају особине и снагу хора античке драме: „Не остављај нас сироте, господине, јер тобом освећени бисмо, и тобом научени бисмо и тобом просветисмо се, пастиру добри, који полажеш душу своју за овце, $\left(\mathrm{J}_{\mathrm{H} .} 10,15\right)$ јер никада у твоје дане вук не уграби овцу од Бога преданог ти стада пастве! И у свих тридесет осам година твојих сачувани бисмо и отхрањени, и другог господина и оца не познасмо осим тебе, господару наш"! (Свети Сава 1998: 157-159). Али дијалог и плачеви се стапају у једну целину и у овом делу задобијају још једно својство - лиричност која је постигнута репликама саглашавања: „И подигавши руке своје блажени, положи их на врат мој грешни, и поче плакати жалосно, слатко своје целовање дарујући ми, поче говорити" (Свети Сава 1998: 177). Ово и слична објашњења која су на истоветан начин дата у делу Светог Саве можемо разумети као сценска упутства, у данашњем смислу речи, за начин приказивања драмског текста које аутор даје извођачима.

Истраживања о делу Светог Саве из аспекта теорије драме показују да је руковање апартуром науке о драми било присутно и у анализама наших угледних истраживача дела Светог Саве. Чак и онда када њихове побуде нису биле такве, да сагледавају Житије господина Симеона из визуре драматургије, избијало је погдешто од особина овог списа што је указивало на његову драмску природу и потенцијал.

Огледајући се у жанру житија, Свети Сава показује изузетну рафинираност ,за складним јединством композиције и израза. Дужина извесних целина у композицији приче условљена је самим значењем догађаја или сцена" (Трифуновић 1972: 13). „Уосталом и сам Сава сведочи да је водио рачуна о сразмерама и композицији. О томе сведоче метакњижевни, односно метатеатарски изрази. Свест о исказивању, комуникација са читалачком публиком избија у више говорних чинова главног лика, односно Светог Саве: „О владавини његовој и држави не исписасмо по реду, што слушасмо и видесмо, да се не умноже речи” или „зато ћу о овом (Симеону) укратко испричати, да се не умножи писање” (Свети Сава 1998: 155) што указује на збијеност исказа која карактерише драму. Објашњавање приповедачког поступка, односно ситуације приповедача, показује се као техничко упутство за писца драме. Ђорђе Трифуновић говори о унтрашњој ступњевитости „која врхунац достиже сценом Симеонове смрти" (Трифуновић 1972: 13). Речником теорије драме речено, реч је о климаксу драме. Природу драмског најтачније арти- 
кулише Милан Кашанин, који смисао конструкције Савиног списа налази „у непрекидном низу драматичних дгађаја" (Кашанин 1975: 130).

Говорећи о суштини дела Живот господина Симеона, он доследно користи терминологију теорије драме: сцена, трагедија, монолог, дијалог.

Сложеност и покретљивост жанра житија, грађеног на противтежи и преплитању „историјског и апстрктног, материјалног и нематеријалног, одређеног и неодређеног” (Трифуновић 1972: 64), могу да проузроче обличје новог жанра. Тако се неки одломци Житија светог Симеона могу схватити као делови драме, без обзира на то што немају паратекст, нормативна средства карактеристична за жанр драме. Такви делови Житија господина Cимеона врло су подесни за сценско изражавање, односно да поседују знатан степен спектакуларности, сценску узбудљивост и узвишеност. Милан Кашанин не мисли да је сврставање Савиног животописа Немањиног у хагиографске књиге исправно, сматрајући да не спада у светачка житија јер је писан „пре канонизовања Немањина, кад монах Симеон још није био проглашен за светитеља и за чудотворца" (Кашанин 1975: 126). Кашанин истиче да насловом дела Живот господина Симеона Сава указује на својства Немањине световне личности, а не светитељске особине. Кашанин, посматрајући његов књижевни склоп, ово дело Светог Саве именује „приповетком са драмским акцентима, одуховљеном атмосфером и поетским осећањем” (Кашанин 1975: 125). А Милорад Панић Суреп тврди да „потреснијих и узвишенијих страница од Савина описа смрти Немањине тешко је наћи у широком опсегу тадашње европске књижевности” (Панић Суреп 1972: 276). Такву чудесну драматску снагу има опис припреме за погреб Стефана Немање: „беше чудо гледати где како туђинац, убог, обавит у расу, пружен на земљи по рогозини, с каменом испод главе, свима се клања, свима умиљава и од свих иште проштења и благослова - онај кога се бојаху и од кога трептаху на све стране" (Свети Сава 1998: 181). Немањино одрицање од престола и његово боловање и предсмртни час, Кашанин идентификује као два средишња догађаја са драматским набојем. „То су две сцене специфичне у којима се тон његовог причања и психологија запажања мењају напоредо са променом личности и тренутка” (Кашанин 1975: 131). И Томислав Јовановић сматра „последње тренутке праштања Симеона са Савом”, најразвијенијом епизодом Житија.” Део Житија заснива се на библијском лиризму ${ }^{1}$ посебне врсте. Као равнотежа неминовности одласка из овоземаљског живота поставља се вечни живот 'у коме нема више растанка"' (Јовановић 1998: XXII). Снажна је такође драмска слика која дочарава канонизовани мизансцен средњовековног ритуалног обреда према којем је организован сабор Стефана Немање када сабира своје синове и бојаре и одриче се престола: „сакупи благородну своју децу и све изабране своје бољаре, мале и велике, и окупивши их око себе, поче им учећи говорити” (Свети Сава 1998: 155). Он говори, молећи: „А мене сада отпустите, владара свог с миром, да виде очи моје спасење, које је спремио

\footnotetext{
1 Лиризам, песничке могућности Светог Саве испољене у Житију господина Симеона, а нарочито у Служби Светоме Симеону ( 1209-1213, 1216-1219) портврђују да су, скоро по правилу, највећи српски песници и најбољи драмски писци.
} 
пред лицем свих, светлост за откриће народима и у славу (Лк 2, 29-31) вама, пастви мојој. Јер видим се како је све сујета, људско, што не остаје после смрти” (Свети Сава 1998: 157). А на сабору „сви су ридали и говорили му”. У Житију Светог Симеона могуће је идентификовати заокружене драмске сцене, слике, призоре: „драмтични чин” одрицања од престола, прекидан ридањем и плачем пастве, крунисање Стефана за великог жупана, уз моралне савете синовима, потом обраћање властели. Све ове сцене подсећају на слике из античке драме. Први део списа Светог Саве намеће се као драмски предложак за монодрамску панораму, а у другом делу запажамо елементе драме са два лика. Посебну вредност има Немањин монолог. Сава га слуша и само повремено понешто пита. Монолог је суптилан, једноставан а ритмичан, динамичан.

И остало што Свети Сава пише о оцу, припада драмским категоријама: намеће се као пролог и епилог. На драмски интентзитет и дожвљај животописа упућује и карактер намене овог жанра. Кашанин нас подсећа да ови текстови, па ни Савин Живот господина Симеона, није намењен да се „чита у самоћи. Они су настали ради тога да се, по манастирским трпезријама, за време обеда, читају наглас. Њима је одавана почаст већ самим тиме што их је слушало мноштво људи, у изузетним часовим, пуним свечности и тишине, у којој се једино чуо глас чтеца." (Кашанин 1975: 103). Тако житије постаје драмским, односно потенцијалним обликом за извођење. У савременом позоришту, дело као што је Житије Светог Симеона, врло је подесно за извођење, без великих интервенција, као драма са два лика и хором.

\section{ЛИТЕРАТУРА}

Кашанин 1975: М. Кашанин, Српска књижевност у средњем веку, Београд: Просвета.

Панић-Суреп 1972: М. Панић-Суреп, Дело Светог Саве, у: Стара књижевност, (прир. Ђорђе Трифуновић), Београд: Нолит, 272-277.

Свети Сава (1998). Сабрана дела, Београд: Српска књижевна задруга.

Трифуновић 1990: Ђ. Трифуновић, Азбучник српских средњовековних књижевних појмова, Београд: Нолит.

Трифуновић 1972: Ђ. Трифуновић, Значајније појаве и писци у старој српској књижевности, у: Стара књижевност, (прир. Ђорђе Трифуновић). Београд: Нолит, 11-30.

Трифуновић 1972: Ђ. Трифуновић, Нацрт за поетику старе српске књижевности, у: Стара књижевност, (прир. Ђорђе Трифуновић), Београд: Нолит, 60-68.

Pavis 2004: P. Patrice, Pojmovnik teatra, Zagreb: Akademija dramske umjetnosti. Molinari 1982: Č. Molinari, Istorija pozorišta, Beograd: Vuk Karadžić. 


\section{Milivoje V. Mlađenović \\ THE CHARACTERISTICS OF DRAMA IN SAINT SAVA'S HAGIOGRAPHY OF SAINT SIMEON}

(Summary)

The aesthetic notion of the dramatic, in terms of contents, denotes, among other things, shifts and trends among the opposites, the battle of ideas, dissonance of the existence. By starting from that specific category, the paper firstly establishes the most significant characteristics of the dramatic in the Žitije Svetog Simeona (Life of Saint Simeon): stage images, dialogue, monologue, conflict, situations, characters and other features which shall then become the subject of an analysis. Their most important characteristics will then be described by using the most prominent examples taken from this very significant piece of writing by Saint Sava. This piece possesses extraordinarily exiting and poetic atmosphere. The conclusion further emphasizes the dramatic power Saint Sava expressed in depicting the images of the land held by the Nemanjić dynasty in the $12^{\text {th }}$ and $13^{\text {th }}$ century and which is comparable to the images from ancient plays. 